\title{
BURKITT'S LYMPHOMA AND SICKLE CELL TRAIT
}

\author{
M. C. PIKE, PH.D. ${ }^{1}$ \\ R. H. MORROW, M.D. \\ A. KISUULE ${ }^{2}$ \\ J. MAFIGIRI ${ }^{2}$ \\ Department of Preventive Medicine, Makerere Medical School, \\ P.O. Box 7072, Kampala, Uganda
}

ONLY two areas of the world, tropical Africa and New Guinea, are endemic for Burkitt's lymphoma. These are the principal areas of the world where malaria still occurs in hyper- and holo-endemic forms, and within these two areas the geographical distribution of the tumour coincides closely with that of endemic malaria.

These observations suggest the possibility of a causal connection between chronic stimulation of lymphoid tissue by malaria and the development of the lymphoma (Dalldorf, Linsell, Barnhart, and Martyn, 1964; Edington, Maclean, and Okubadejo, 1964; Burkitt, 1969).

Young children with AS haemoglobin (sickle cell trait) are substantially protected against severe falciparum malaria (Allison, 1963). If they could be shown to have a lower incidence of Burkitt's tumour than children with AA haemoglobin, it would provide additional evidence for a role of falciparum malaria in the aetiology of the disease.

Williams (1966) compared the haemoglobin electrophoretic patterns of 100 microscopically proven Burkitt's lymphoma patients from Nigeria with those of control children, and he concluded that children with haemoglobin AA were more susceptible to the tumour than those with AS.

This paper describes the preliminary results of a patient-control study in Uganda to test this hypothesis further.

\section{METHOD}

Patients with microscopically proven Burkitt's tumour presenting at the Lymphoma Treatment Centre, Mulago Hospital, Kampala, were individu-

'On secondment from the Medical Research Council's Statistical Research Unit, London

Present address: Department of the Regius Professor of Medicine, Radcliffe Infirmary, Oxford

'Medical Assistant. Employed by Dr. Morrow under the U.S. National Cancer Institute (N.I.H.) Contract No. PH-43-67-47. ally matched with one or two unrelated persons of the same age, sex, tribe, and place of residence. These 'neighbour controls' were chosen by visiting, in a predetermined order, the homes nearby the home of onset of the patient until one or two suitable subjects were found.

The haemoglobin electrophoretic pattern of all patients and controls was determined by paper electrophoresis.

\section{RESULTS}

Table I gives our results to date. The 10 possible haemoglobin electrophoretic combinations are listed separately. Combinations $1,2,3$, and 4 are noninformative as to whether AS is associated with

TABLE I

PRELIMINARY RESULTS FROM UGANDA

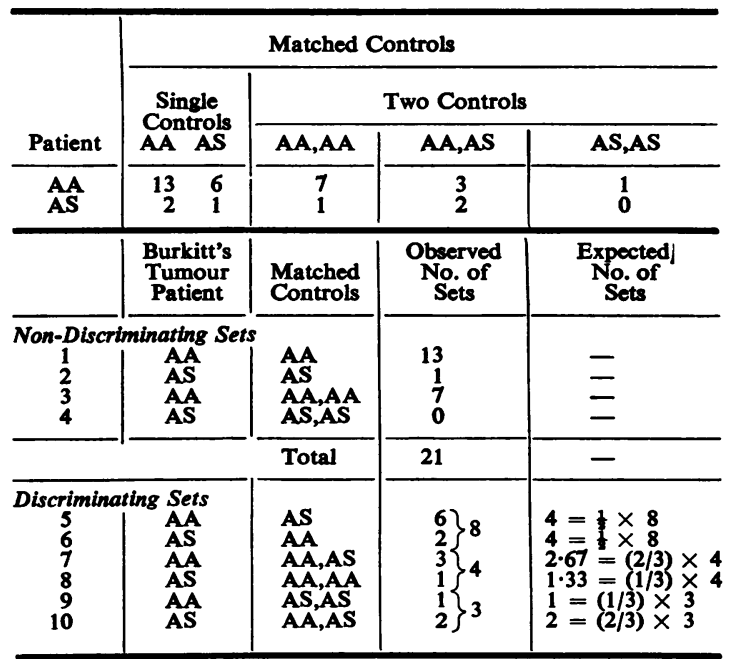

Matched with patients by age, sex, tribe, and place of residence 
Burkitt's lymphoma (see Pike and Morrow, 1969). Evidence for AS being protective is provided by combinations 5,7 , and 9 , and evidence against by combinations 6,8 , and 10 .

These figures provide some support for the protective hypothesis, but the result is not statistically significant, $P$ (1-sided) $=0 \cdot 16$ (for method of calculation see Pike and Morrow, 1969).

TABLE II

RESULTS FROM NIGERIA

\begin{tabular}{|c|c|c|c|}
\hline $\begin{array}{c}\text { Haemoglobin } \\
\text { Genotype }\end{array}$ & $\begin{array}{c}\text { Ibadan Hospital } \\
\text { Burkit's Tumour } \\
\text { Patients }\end{array}$ & $\begin{array}{l}\text { Ibadan } \\
\text { Hospital } \\
\text { Controls }\end{array}$ & $\begin{array}{l}\text { Ilora } \\
\text { Village } \\
\text { Controls }\end{array}$ \\
\hline $\begin{array}{c}\text { AA } \\
\text { AS } \\
\text { SC,SS,CC,AC }\end{array}$ & $\begin{array}{rr}78 & (78.0 \%) \\
17 & (17.0 \%) \\
5 & (5.0 \%)\end{array}$ & $\begin{array}{rr}225 & (68.0 \%) \\
95 & (28.7 \%) \\
11 & (3.3 \%)\end{array}$ & $\begin{array}{rr}142 & (70.3 \%) \\
49 & (24.3 \%) \\
11 & (5.4 \%)\end{array}$ \\
\hline Total & $100(100 \cdot 0 \%)$ & $331(100 \cdot 0 \%)$ & $202(100.0 \%)$ \\
\hline
\end{tabular}

The Nigerian results reported by Williams (1966) are given in the first two columns of Table II. All his Burkitt's tumour patients had attended Ibadan Hospital at some time during the period 1960-65, were members of the Yoruba tribe, and were between the ages of 5 and 15 years. There were 60 boys and 40 girls. He used, as controls, 331 Yoruba patients who attended the same hospital over the same period and who were within the same age range. A corrected chi-squared test of $\mathrm{AA}$ against $\mathrm{AS}$ of these lymphoma patients against these hospital controls gives $P$ (2-sided) $=0.03$.

Table II, column 3, gives the results of a survey in Ilora Village of Yoruba children aged 6 to 12 years (Roberts and Boyo, 1962). The proportion of AS children is smaller in the Ilora Village survey than in William's Ibadan Hospital controls. A corrected chi-squared test of AA against AS of the Ibadan Burkitt's lymphoma patients against these Ilora Village children is not significant, P (2-sided) $=0 \cdot 18$.

\section{Discussion}

In tropical Africa the prevalence of AS varies widely from one community to another and within a particular community it usually varies with age. The major reason for the geographical differences is the considerable variation in the intensity of falciparum malaria infection. In addition, migration, relative isolation of populations, and inter-marriage can lead to a very local AS:AA ratio. The presence of other haemoglobin genotypes may also affect the prevalence pattern.

In areas of hyper- or holo-endemic falciparum malaria, possession of AS haemoglobin is of particular importance in early childhood before the development of acquired immunity. In these areas, the AS:AA ratio increases with age up to 5 or 10 years, and may continue to increase even to adulthood in certain circumstances: Roberts and Boyo (1962) have provided some evidence of this latter phenomenon among the Yoruba. In communities which are free or relatively free of malaria or in communities that have introduced mosquito control or anti-malarial prophylaxis, the ratio would not increase with age and might decline if AS children suffer from certain diseases more commonly than AA children (Motulsky, 1964).

If conditions of exposure to malaria were different for boys than for girls in a given community, then the AS:AA ratio might also vary with sex.

In any study attempting to relate sickle cell trait to another condition, it is essential, therefore, to control for age, geographic location, tribal group, and sex.

In Nigeria the frequency of the sickling gene is considered to be uniform throughout the Yoruba area at any given age. Children from Ilora Village may, therefore, provide an adequate geographic, tribe, and sex control group for the Ibadan Hospital Burkitt's lymphoma patients; but they need to be more accurately age matched with the patients.

The difference between the Ilora Village results and the Ibadan Hospital control results is noto statistically significant and could be due to chance.? However, persons with AS haemoglobin may have more severe manifestations in certain diseases (Motulsky, 1964), and hospitalized patients may therefore have a higher prevalence of AS than the reference population and should not be used as controls.

In Uganda the distribution of the sickling gene varies considerably from district to district, and may differ markedly within a district even among one particular ethnic group (Livingstone, 1967; Hall, 1968). The 'nearest neighbour' method of choosing controls used in this study is therefore essential in this country.

Our results so far point to a decreased incidence of Burkitt's lymphoma among AS children. It is estimated that 150 patients and their controls will need to be investigated for the result to be statistically significant at the $5 \%$ level. It will take a considerable time to find this number of Burkitt's lymphoma patients for study in Uganda: similar investigations need to be undertaken in other parts of Africa where the tumour, the sickling gene, and falciparum malaria are all common if this important question is to be settled soon.

It could well be that the AS protection rate against Burkitt's lymphoma is greater in the young before 
acquired immunity to malaria has developed. Testing this hypothesis must await the collection of further data.

Relative risks can be calculated from this kind of study only by making the assumption that the controls are a representative sample of the population at risk. The above arguments show that this is a hazardous procedure. We have done it, however, in order to obtain some idea of the importance to attach to these results-the computations show that persons with AA haemoglobin appear to have approximately twice the risk of developing Burkitt's lymphoma as do those with AS.

\section{SUMmaRY}

A study in Uganda comparing the haemoglobin electrophoretic pattern of 36 Burkitt's lymphoma patients with their nearest neighbours of the same age, sex, and tribe points to a substantially decreased frequency of AS haemoglobin in the Burkitt's tumour patients. Persons with AA haemoglobin appear to have about twice the risk of developing the lymphoma as do those with AS.

This result does not attain statistical significance. It is estimated that 150 patients and their controls will need to be investigated for the result to be significant at the $5 \%$ level. It is not possible to reach this number in a reasonably short time working in Uganda only: collaboration with workers in other areas of Africa where Burkitt's lymphoma, the sickling gene, and falciparum malaria are all common is essential.

We gratefully acknowledge the financial support of the U.S. National Cancer Institute (N.I.H.) under their Contract Nos. PH-43-67-47 and PH-43-67-1343 (L.T.C.) and of the British Empire Cancer Campaign for Research.
We wish to thank Dr. L. Fass, Professor S. Kyalwazi, and Dr. J. Ziegler for permitting us to study their patients; and Dr. F. Lothe and his staff of the Department of Haematology, Mulago Hospital, for doing the paper electrophoresis.

\section{REFERENCES}

Allison, A. C. (1963). Inherited factors in blood conferring resistance to protozoa. In Immunity to Protozoa. p. 109. Ed. Garnham, P. C. C., Pierce, A. E., Roitt, I. Blackwell Scientific Publications, Oxford.

BURKITT, D. P. (1969). Etiology of Burkitt's lymphoma -an alternative hypothesis to a vectored virus. $J$. nat. Cancer Inst., 42, 19.

Dalldorf, G., Linsell, C. A., Barnhart, F. E., and MARTYN, R. (1964). An epidemiologic approach to the lymphomas of African children and Burkitt's sarcoma of the jaws. Perspect. Biol. Med., 7, 435.

Edington, G. M., Maclean, C. M. U., and Okubadejo, O. A. (1964). In The Lymphoreticular Tumours in Africa. A Symposium organised by the International Union against Cancer, Paris, 1963. p. 236. Ed. Roulet, F. C. Karger, Basle and New York.

Hall, S. A. (1968). In Uganda Atlas of Disease Distribution, p. 109. Ed. Hall, S. A., and Langlands, B. W. Makerere University College, Kampala.

Livingstone, F. B. (1967). Abnormal Haemoglobins in Human Populations. Aldine Publishing Company, Chicago.

Motulsky, A. G. (1964). Hereditary red cell traits and malaria. Amer. J. trop. Med. Hyg., 13, 147.

PIKe, M. C., and Morrow, R. H. (1969). A note on the statistical analysis of patient-control studies in epidemiology: factor under investigation an all-or-none variable. Brit. J. prev. soc. Med., $24,42$.

ROBERTS, D. F., and BoYo, A. E. (1962). Abnormal haemoglobins in childhood among the Yoruba. Hum. Biol., 34, 20.

Williams, A. O. (1966). Haemoglobin genotypes, ABO blood groups, and Burkitt's tumour. J. med. Genet., 3, 177. 